\title{
A Rare Cause of Complete Atrioventricular Block: Lyme Carditis
}

\author{
Mesut Aydin ${ }^{1, *}$, Serkan Bulur ${ }^{1}$, Yasin Turker ${ }^{1}$, Kezban Ozmen Suner $^{2}$, Ahmet Sahin $^{3}$, Hakan Ozhan $^{1}$ \\ ${ }^{1}$ Department of Cardiology, Duzce Medical School, Duzce University, 81620 Konuralp, Duzce, Turkey \\ ${ }^{2}$ Department of Chest Disease, Duzce Medical School, Duzce University, 81620 Konuralp, Duzce, Turkey \\ ${ }^{3}$ Department of Infectious Disease, Duzce Medical School, Duzce University, 81620 Konuralp, Duzce, Turkey
}

\begin{abstract}
Lyme disease is a tick-borne spirochete infection that may affect the heart. Cardiac manifestations include conduction disturbances and other pathologies of the heart. Disturbance of atrioventricular (AV) node conduction is the most common cardiac manifestation of Lyme disease. We report a 61-year old female, who was admitted to the emergency department with the complaints of syncope, dizziness and generalized fatigue. Physical examination revealed normal findings. The patient's electrocardiogram on admission revealed a newly diagnosed bradycardia due to third degree of AV block with $40 / \mathrm{min}$ ventricular rate. The patient was admitted to the coronary care unit and was placed a transvenous pacemaker. Lyme serology and Western blot were positive for Borrelia antibodies. The symptoms and AV block resolved completely after doxycycline therapy.
\end{abstract}

Keywords Tick, Lyme Disease, Lymecarditis, Atrioventricular Block

\section{Introduction}

Lyme borreliosis is a tick-borne disease that is known to affect primarily the skin, heart, nervous system, and joints. Generally, cardiac complications occur in the earlydisseminated phase. Disturbance of atrioventricular (AV) nodal conduction is the most common cardiac manifestation of Lyme disease. In this report, a patient with complete AV block caused by Lyme disease was presented and relevant literature also was reviewed.

\section{Case Presentation}

A 61-year-old woman without history of cardiovascular diseases was admitted to the emergency department with complaints of syncope, dizziness and generalized fatigue. The pulse was 40 beats per minute and blood pressure was $90 / 60 \mathrm{mmHg}$. There were no abnormal findings other than a slight redness in the right upper arm on physical examination. She also did not use any drugs or medication and no history of tick bite. The patient's ECG revealed third degree AV block (Figure 1).

Complet blood count and standard biochemistry tests were performed. Results were as follows: Erythrocyte

* Corresponding author:

hekimmesut@yahoo.com (Mesut Aydin)

Published online at http://journal.sapub.org/cmd

Copyright (C) 2012 Scientific \& Academic Publishing. All Rights Reserved sedimentation rate $54 \mathrm{~mm} / \mathrm{h}$, Aspartate aminotransferase 104 IU/l, alanine aminotransferase $212 \mathrm{IU} / 1$ (Table 1).Other laboratory results were normal. There was no pathology on the chest X-ray. The patient was admitted to the coronary care unit. A temporary pacemaker was inserted.

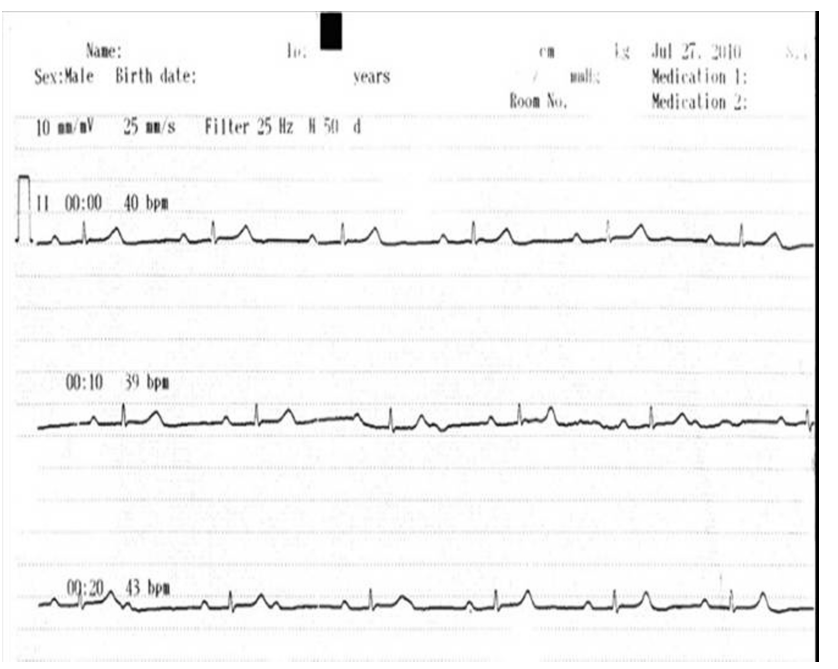

Figure 1. ECG on admission showing third degree AV block

Acute coronary syndrome was ruled out by serial ECG's and cardiac enzymes. $\operatorname{lgM}$ and IgG antibody levels (Novalisa ELISA Test Kits; NovaTecImmundiagnostica $\mathrm{GmbH}$; Dietzenbach, Germany) for Borreliaburgdorferiwere 3,19 IU and 4,47 IU, respectively( Table 1). The serum was collected on the next day of admission. Doxycycline $100 \mathrm{mg}$ p.o. daily was started. All symptoms and AV block completely recovered within three days of antibiotic therapy. 
Pacemaker was removed. Control ECG revealed normal sinus rhythm (Figure 2).

Table 1. Laboratory results of patient

\begin{tabular}{|c|c|c|}
\hline & Results & Normal values \\
\hline Borreliaburgdorferi antibody IgM & $3,19 \mathrm{IU}$ & $0,40-2,30 \mathrm{IU}$ \\
\hline Borreliaburgdorferi antibody IgG & $2,30 \mathrm{IU}$ & $7,0-16,0 \mathrm{IU}$ \\
\hline BUN $\quad(\mathrm{mg} / \mathrm{dl})$ & 13.55 & $8-23$ \\
\hline Glucose $\quad(\mathrm{mg} / \mathrm{dl})$ & 97 & $74-109$ \\
\hline Urea $\quad(\mathrm{mg} / \mathrm{dl})$ & 29 & $13-43$ \\
\hline Creatinine $(\mathrm{mg} / \mathrm{dl})$ & 0.79 & $0,5-0,9$ \\
\hline AST $\quad(\mathrm{IU} / \mathrm{L})$ & 104 & $5-32$ \\
\hline ALT $\quad(I U / L)$ & 212 & $5-33$ \\
\hline Sodium & 139 & $136-145$ \\
\hline Potassium $\quad(\mathrm{mEq} / \mathrm{L})$ & 4.56 & $3,5-5,1$ \\
\hline Clor $\quad(\mathrm{mEq} / \mathrm{L})$ & 105.6 & $98-110$ \\
\hline$(\mathrm{IU} / \mathrm{L})$ & 127 & $26-192$ \\
\hline CK-MB $\quad(\mathrm{IU} / \mathrm{L})$ & 9.8 & $3-25$ \\
\hline Troponin $\quad(\mathrm{ng} / \mathrm{ml})$ & $<0.2$ & $0-1$ \\
\hline WBC & 7030 & $5200-12400$ \\
\hline Hemoglobin $(\mathrm{g} / \mathrm{dl})$ & 12.7 & $12-18$ \\
\hline $\mathrm{HCT}(\%)$ & 40.9 & $37-52$ \\
\hline $\mathrm{MCV}$ & 86.2 & $80-99$ \\
\hline $\mathrm{MCHC}$ & 34.5 & $33-37$ \\
\hline Platelet $\left(10^{3} / \mathrm{uL}\right)$ & 151 & $130-400$ \\
\hline TSH(uIU/ml) & 0.997 & $0,4-4,0$ \\
\hline $\operatorname{ESR}(\mathrm{mm} / \mathrm{h})$ & 54 & $0-20$ \\
\hline
\end{tabular}

ALT: Alanine Aminotransferase, AST: Aspartate Aminotransferase, BUN:Bloo urea nitrogen, CK: CreatineKinaze, CK-MB: Creatine Kinaz- Myocardial Band, ESR: Erythrocyte Sedimentation Rate, HCT:Hematocrit, IgG:Immunuglobulin G, IgM:Immunuglobuline M, MCV: Mean corpuscular volume, MCHC: Mean corpuscular hemoglobinconsantration, TSH: Thyroid stimulating hormone, WBC:White blood cell,

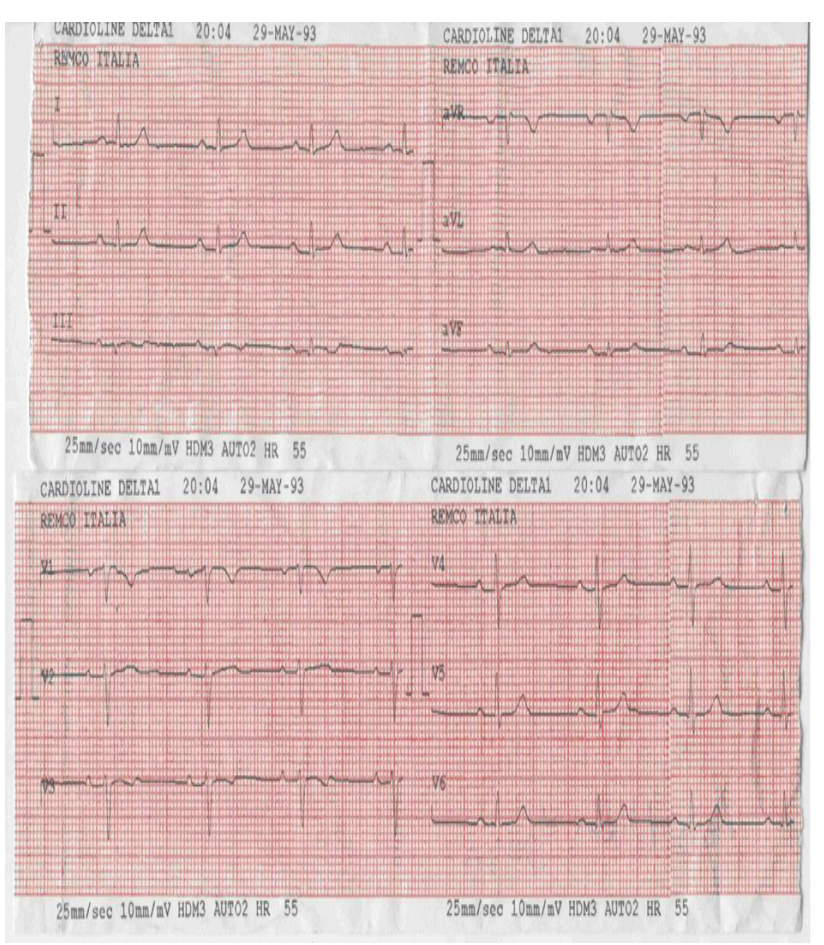

Figure 2. ECG after treatment with restored sinus rhythm

24-hour Holter monitoring also showed normal sinus rhythm without any AV block. The patient was discharged and she had no complaints at the first- month visit.

\section{Discussion}

Lyme Borreliosis (LB) have been reported after 1990's in Turkey and the spirochete was isolated from the tick vectors[1]. Lyme carditis is a rare manifestation of the disease. It occurs in $1.5 \%-10 \%$ of cases in North America and $0.5 \%-4 \%$ in Europe[2]. There are various symptoms of acute cardiac involvementsuch as exertionaldyspnea, chest pain, palpitation and syncope with a reported rate of $4-10 \%$ in patients who have Lyme disease[3,4]. The most frequent cardiac manifestation is conduction abnormalities including transient atrioventricular (AV) heart block, junctional rhythm and asystolic pauses. Van der Linde et al.[5] reported the AV block rates as $49 \%$ for third degree, $16 \%$ for second degree and $12 \%$ for first degree in this disease. In addition, the involvement of myocardium and pericardium was reported in the course of disease[7].

There are a number of non-invasive tests such as gallium scanning and indium-labeled anti-myosin antibody scanning toevaluate the myocardial involvement in Lyme carditis[8]. Magnetic resonance imaging canalsobeused fordiagnosingthe acute carditisin positive cases[9]. In addition, cardiacbiomarkersmay be useful in the diagnosis of acute myocarditis andpericarditis[10]. Echocardiography has a low diagnostic value for the detect of Lyme carditis because of it reveals generally normal heart function. However, echocardiography can be used for monitoring the development of dilated cardiomyopathy[11].

On the other hand, serology is usually the first and often the only supportingdiagnostic measure to be deployed, because it is relatively easy to perform with acceptable sensitivity and specificity[12]. The most frequently usedserologic tests are enzyme-linked immunosorbent assay (ELISA), immunofluorescence assays and Western blotting[13]. Generally, the sensitivity of ELISA is less than $50 \%$ in acute-phase of patients with erythema migrans(EM). Sensitivity increases rapidly over time after the first week in untreated patients with EM. In addition, sensitivity is very high in patients with objective evidence of extracutaneous involvement (e.g., carditis or neuroborreliosis)[14]. Whole-cell antigen preparations lack specificity because of the presence of cross-reacting antigens of B. burgdorferibroadly. These include common bacterial antigens such as heat shock proteins, flagellarantigens, and others[15]. In this case we have used ELISA kits. However, the limitations of antibody tests must be appreciated. Antibody response in early LB may be weak or absent. On the other hand, a positive specific antibody response may persist for months or even years after successful treatment of the infection, so follow-up of antibody titres in patients following therapy is not a reliable approach for monitoring success of treatment.

Temporary cardiac pacing may be required almost a third of cases of Lyme carditis and complete recovery occurs in more than $90 \%$ of patients. It has been suggested that the Lyme disease affects the conduction system as a result of the direct dissemination of spirochetes into cardiac tissues, the inflammatory response associated with the infection, or 
both[16].

It has been reported that antibiotic therapy in the early stages of disease prevents the later complications[17]. Patients with minor cardiac involvement (first-degree AV block with PR interval $<0.3 \mathrm{~s}$ ) could be treated orally with doxycycline, tetracycline or amoxicillin[18]. Doxycycline is preferable because of its higher efficacy in other tick borne diseases (babesiosis, ehrlichiosis, anaplasmosis) that could be co-transmittedand might aggravate the outcome[19].

Patients with more severe conduction system disturbances (first-degree AV block with a PR interval $>0.3 \mathrm{~s}$, second or third-degree AV block) should be hospitalized in a coronary care unit and given either intravenous ceftriaxone or high-dose intravenous penicillin G. Insertion of a temporary transvenous pacemaker could also be consideredaccording to patients's clinic status. In the literature, permanent pace maker was used in only one case because ofrefractoryAV blockto aggressive pharmacological therapy. In all other cases, permanent pacemakers were implanted prior to the definitive diagnosis of Lyme disease[20].

\section{Conclusions}

In the patients who haveAV block of unknown cause, Lymecarditis may be considered as the alternative diagnosis. Early testing and initiation of antibiotic treatment is essential to prevent the later complications. Thus, early diagnosis and treatment may be avoided unnecessary implantation of a pacemaker.

\section{REFERENCES}

[1] Polat E, Turhan V, Aslan M, Müsellim B, Onem Y, Ertuğrul B. First report of three culture confirmed human lyme cases in Turkey. Mikrobiyol Bul.2010; 44:133-9.

[2] Vasiljevic Z, Dimitrovic R, Naumovic Z, Ostojic M, Radosavlievic M, Karadzic A, Prostran M, Colic M. Common form of Lyme Borreliosiscarditis-complete heart block with syncope:report on 3 cases. Cardiology. 1996:87:76-8.

[3] Grzesik P, Oczko-Grzesik B, Kepa L. Cardiacmanifestations of Lymeborreliosis. PrzeglEpidemiol 2004;58:589-96.

[4] Franck H, Wollschlager H. Lymecarditis and symptomaticsinusnodedysfunction. Z Kardiol 2003;92:1029-32.

[5] Van der Linde MR. Lymecarditis: clinicalcharacteristics of 105 cases. Scand J InfectDisSuppl 1991;77:81-4.
[6] Van der Linde MR, Crijns HJ, Lie KI. Transientcomplete AV block in Lymedisease: electrophysiologicobservations. Chest 1989;96:219-21.

[7] Munk PS, Orn S, Larsen AI. Lymecarditis: persistentlocaldelayedenhancementbycardiacmagneticresonanceimaging. Int J Cardiol 2007;115:e108-10.

[8] Bergler-Klein J, Sochor H, Stanek G, Globits S, Ullrich R, Glogar D. Indium 111 monoclonalantimyosinantibody and magneticresonanceimaging in the diagnosis of acuteLymemyopericarditis. ArchInternMed 1993;153:2696-700.

[9] Karadag B, Spieker LE, Schwitter J, Ruschitzka F, Lüscher TF, Noll G, Corti R. Lymecarditis: restitutio ad integrumdocumentedbycardiacmagneticresonanceimaging. CardiolRev Jul-Aug 2004;12(4): 185-7.

[10] Sauvant G, Bossart W, Kurrer MO, Follath F. Diagnosis and course of myocarditis: a survey in the medicalclinics of $\mathrm{Zu}-$ richUniversityHospital 1980 to 1998. SchweizMedWochenschr 2000;130:1265-71.

[11] Seinost G, Gasser R, Reisinger E, et al. Cardiacmanifestations of Lymeborreliosiswithspecificreferencetocontractiledynfunction. ActaMedAustriaca 1998;25:44-50.

[12] Aguero-Rosenfeld ME, Wang G, Schwartz I, Wormser GP. Diagnosis of Lyme borreliosis. ClinMicrobiol Rev.2005; 18: 484-509

[13] Tugwell P, Dennis DT, Weinstein A, Wells G, Shea B, Nichol G, Hayward R, Lightfoot R, Baker P, Steere AC. Laboratory evaluation in the diagnosis of Lyme disease: Ann Intern Med. 1997;127:1109-23.

[14] Dressler F, Whalen JA, Reinhardt BN, SteereAC.Western blotting in the serodiagnosis of Lyme disease. Jinfect Dis. 1993;167:392-400.

[15] Engstrom SM, Shoop E, Johnson RC. Immunoblot interpretation criteria for serodiagnosis of early Lyme disease. J Clin Micro-biol. 1995: 33:419-27.

[16] Barthold SW, Persing DH, Armstrong AL, Peeples RA: Kinetics of Borelliaburgdorferi dissemination and evolution of disease after intradermal inoculation of mice. Am J Pathol. 1991;139:263-73.

[17] Luft BJ, Goveric PD, Halperin JJ, Volkman DJ, Dattwyler RJ. A perspective on the treatment of Lyme borreliosis: Rev Infect Dis. 1989; 6:1518-25.

[18] Chen SM, Dumler S, Bakken JS, and Walker DH. Identification of a granulocytotropicehrlichia species as the etiologic agent of human disease. J ClinMiclobiol. 1994:32:589-95.

[19] McAlister HF, Klementowicz PT, Andrews C, Fisher JD, Feld M, Furman S. Lyme carditis: an important cause of reversible heart block. Ann Intern Med. 1989;110:339-45. 